\title{
Judgment and Practice in Reid and Wittgenstein
}

\section{Patrick Rysiew}

\section{OpenEdition}

\section{Journals}

Electronic version

URL: http://journals.openedition.org/ejpap/1042

DOI: 10.4000/ejpap.1042

ISSN: 2036-4091

\section{Publisher}

Associazione Pragma

\section{Electronic reference}

Patrick Rysiew, « Judgment and Practice in Reid and Wittgenstein », European Journal of Pragmatism and American Philosophy [Online], IX-2 | 2017, Online since 22 January 2018, connection on 19 April 2019. URL : http://journals.openedition.org/ejpap/1042 ; DOI : 10.4000/ejpap.1042

This text was automatically generated on 19 April 2019

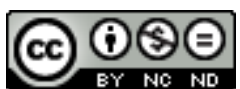

Author retains copyright and grants the European Journal of Pragmatism and American Philosophy right of first publication with the work simultaneously licensed under a Creative Commons AttributionNonCommercial-NoDerivatives 4.0 International License. 


\title{
Judgment and Practice in Reid and Wittgenstein
}

\author{
Patrick Rysiew
}

\section{Introduction}

1 This paper considers the views of two figures whose work falls on either side of the heyday of American pragmatism, Thomas Reid (1710-96) and Ludwig Wittgenstein (1889-1951). The broad similarities between Reid's and (the later) Wittgenstein's views, and in particular their epistemological views, has been well documented (see $n .22$ below). Here, I argue that such similarities extend to the relation in their work between common sense and the presence of elements in their thought that can be considered pragmatist in some interesting and important respect.

Beginning with Reid, I argue that some specific theses commonly associated with pragmatism - e.g., that meaning, truth, or the justifiedness of a belief is a matter of practical effects or efficacy - clearly run counter to his stated views, and stand in tension with the well-known common sense character of his work. At the same time, however, and as others have noted, other pragmatist themes and ideas - e.g., about the close relations between belief (and doubt) and action, theory and practice, and facts and values - do have a clear precedent in Reid (\$2). Most fundamentally, however, Reid's epistemological views in particular display an adherence to the idea that practice is somehow primary - an idea that's central to pragmatism 'broadly conceived', as Brandom calls it and, according to some others (e.g., Putnam, Cavell), to pragmatism per se. What's more, once we are clear on the respects in which Reid's views do incorporate an important pragmatist element, it becomes clear that far from being at odds with, or needing supplementation by, the latter, common sense is in fact inseparable from it (\$3).

Finally, I turn (\$4) to Wittgenstein, and suggest that the same close connection between pragmatist elements and common sense as we find in Reid is present here as well: like Reid, Wittgenstein rejects several 'narrow' pragmatist theses; but he too ascribes practice a crucial role. And while he seldom explicitly refers to common sense, the notions of good 
judgment, and of the reasonable person - hallmarks of common sense, as Reid conceives of it - are at the heart of Wittgenstein's later epistemological views.

\section{Reid (and Peirce) on Belief and Doubt}

One respect of similarity between Reid's views and ideas closely associated with the pragmatist tradition concerns his treatment of belief and, relatedly, of doubt. To set the stage here, it's useful to consider the criticism of Reid that he attributes to us - that is, to normal humans - beliefs that it is in fact doubtful that we all hold.

Central to Reid's common sense philosophy is the idea of 'first principles,' which he divides into First Principles of Necessary Truths, and First Principles of Contingent Truths (1785: 6.5-6.6, pp. 467-512). The former include metaphysical principles such as that whatever begins to exist must have a cause, through to moral principles such as that an unjust action has more demerit than an ungenerous one. The latter include such propositions as that nature is uniform, that the things of which I am conscious, and those which I distinctly remember or perceive, do exist, that testimony is a fundamental source of evidence, and that the natural faculties, by which we distinguish truth from error, are not fallacious. Among Reid's claims here are that such principles are "universally believed" (1785: 1.2, pp.44-6; 6.4, pp. 465-6), and indeed that they "are no sooner understood than they are believed. The judgment follows the apprehension of them necessarily, and both are equally the work of nature, and the result of our original powers" (1785: 6.4, p. 452).

But are these principles such that we all - at least, all of us who are sane, and who understand them - believe them? Some have found that incredible. Thus, for example, Nicolas Wolterstorff has argued that, while (normal) humans may indeed all take for granted Reid's first principles, we shouldn't conflate this point, as Reid does, with the dubious idea that they are universally believed:

most people surely don't actually believe those propositions that all those of us who are normal adults must take for granted in our living of life in the everyday. Most people haven't even so much as entertained them, let alone believed them. (Wolterstorff 2001: 225; cf. 2004: 93)

Notice, however, that this objection requires that we think of belief at its most explicit as involving conscious consideration of the belief's object or content. But that beliefs are generally like that is clearly not Reid's view. For example, speaking of the seventh first principle of contingent truths - "That the natural faculties, by which we distinguish truth from error, are not fallacious" (1785: 6.5, p. 480) - Reid says:

We may here take notice of a property of the principle under consideration, that seems to be common to it with many other first principles [...]; and that is, that in most men it produces its effect without ever being attended to, or made an object of thought. No man ever thinks of this principle, unless when he considers the grounds of scepticism; yet it invariably governs his opinions. (1785: 6.5, pp. 481-2)

More generally, belief is not simply a specific type of 'attitude towards a proposition' for Reid. Belief must indeed "have an object," Reid says: "he that believes must believe something; and that which he believes, is called the object of his belief" (1785: 2.20, p. 227). When we specify or make explicit the belief's object - or, as we would say, its content - we do so by using a complete sentence, in subject-predicate form. As Reid puts it, belief "is always expressed in language by a proposition, ${ }^{1}$ wherein something is 
affirmed or denied." (1785: 2.20, p. 228). However, as Angélique Thébert observes, most often our beliefs are not so expressed (2015: 203); and - as already noted, and as the above passage makes clear - a belief or its content (or "object") need not for Reid be something to which we reflectively attend. So we can agree with Wolterstorff that "[m]ost people haven't even so much as entertained" the propositions by which Reid expresses his first principles. Even so, they may well have the relevant beliefs. Belief is the "the main spring in the life of a man" (1785: 2.20, p. 228); our beliefs are manifested in our thoughts and actions. ${ }^{2}$ And Reid frequently speaks of our thought and conduct as manifesting an 'implicit belief' (e.g., 1764: 1.3, p. 16; 6.20, p. 170; 1788: 3.1.2, p. 87), an 'instinctive belief' (1788: 3.1.2, p. 87), an 'implied conviction' (1785: 6.5, p. 479), an 'inward conviction' (1785: 6.5, p. 482), or an 'implicit faith' (1785: 6.5, p. 477), in the first principles: ${ }^{3}$

Our ordinary conduct in life is built upon first principles, as well as our speculations in philosophy; and every motive to action supposes some belief [...]. (1785: 6.4, p. 464)

Who can doubt [...] whether mankind have, in all ages, believed the existence of a material world, and that those things which they see and handle are real, and not mere illusions and apparitions? Who can doubt whether mankind have universally believed that everything that begins to exist, and every change that happens in nature, must have a cause? Who can doubt whether mankind have been universally persuaded that there is a right and a wrong in human conduct? - some - things which, in certain circumstances, they ought to do, and other things which they ought not to do? The universality of these opinions, and of many such that might be named, is sufficiently evident, from the whole tenor of men's conduct, as far as our acquaintance reaches, and from the records of history, in all ages and nations, that are transmitted to us. (1785: 1.2, p. 45)

As noted above, the picture of belief that emerges here has obvious affinities to the pragmatists', and perhaps most especially to the views of C. S. Peirce, who characterizes belief as "a rule active in us" (CP 2.643), "a general principle working in man's nature to determine how he will act" ( $\mathrm{CP}$ 2.170), and as "something on which a man is prepared to act and...therefore, in a general sense, a habit" (CP 2.148). ${ }^{4,5}$ The intimate connection between belief and action, moreover, lies behind Reid's frequent criticisms of the sceptic as somehow insincere - criticisms that Peirce would later echo with his well-known distinction between real and merely professed or "paper" doubt (e.g., CP 5.514; see Lundestad 2008: 177). Thus, the sceptic is, as Peirce would say, a "breath holder" (CP 5.499); or, as Reid puts it, scepticism is a "chamber exercise" or "hobby-horse" (1764: 2.6-7, p. 36) that no sane person can actually maintain:

even those who reject [one or another first principle] in speculation, find themselves under a necessity of being governed by it in their practice. (1785: 6.5, p. 480)

I never heard that any sceptic run his head against a post, or stepped into a kennel, because he did not believe his eyes. (1785: 1.2, p. 46)

If a man pretends to be a sceptic with regard to the informations of sense, and yet prudently keeps out of harm's way as other men do, he must excuse my suspicion, that he either acts the hypocrite, or imposes upon himself. For, if the scale of his belief were so evenly poised as to lean no more to one side than to the contrary, it is impossible that his actions could be directed by any rules of common prudence. (1764: 6.20, p. 170)

10 Common sense philosophy, with its appeal to features of our everyday practice, has often met with the charge of philosophical irrelevance, ${ }^{6}$ and Reid's claims here are no exception. Thus, for example, Lynd Forguson argues that the point Reid is making in passages such as the foregoing is "nothing more than an ad hominem: the sceptic does not, 
and cannot, practice what he preaches, an observation which Hume freely admitted" (Forguson 1989: 112). Likewise, Philip de Bary argues that Reid's frequent claims that sceptics "do not practice what they preach" are "shallow" (2002: 7) and not a proper part of his response to scepticism. ${ }^{7}$ De Bary writes:

one of Reid's favourite objections to scepticism - that sceptical conduct is deplorably inconsistent with sceptical principle - is superficial. Reid is disingenuous in his characterization of both the conduct and the principle; and it seems fair to conclude that his accusations of inconsistency between them are part of his polemic, not his reasoned arguments, against scepticism. (De Bary 2002: 12)

11 As several commentators have argued, however, this dismissal seems too quick; arguably, it rests on a mistaken view of just what Reid's point here is. Specifically, and as with Wolterstorff's objection above, the present criticism overlooks how Reid conceives of belief and its relation to action. For, given Reid's views on the latter, his point is not merely that the sceptic's practice is inconsistent with his theory; it is, rather, that the sceptic's behavior manifests an inconsistency among beliefs. ${ }^{8}$ This is not because, as Reid sees it, for some first-order proposition such as that there is a cup on the table the sceptic believes $p$ in practice but, at the level of theory, believes not- $p$ (Ferreira 1986: 129). As has been pointed out, sceptical doubts aren't typically directed at such first-order propositions at all. What the sceptic means to call into question is whether those beliefs are reliably formed, justified, or apt to constitute knowledge. ${ }^{9}$ But it is precisely here, it has been suggested, that Reid means to locate the inconsistency in question: not only must - as hardly anyone denies - the sceptic form the relevant first-order beliefs, he cannot sustain the theoretical metabelief about such first-order beliefs' supposed lack of justification (Ferreira 1986: 129). For the formation of a given perceptual belief carries with it an implicit commitment to the trustworthiness of the testimony of the senses: ${ }^{10}$

We are born under a necessity of trusting to our reasoning and judging powers; and a real belief of their being fallacious cannot be maintained for any considerable time by the greatest sceptic, because it is doing violence to our constitution. It is like a man's walking upon his hands, a feat which some men upon occasion can exhibit; but no man ever made a long journey in this manner. Cease to admire his dexterity, and he will, like other men, betake himself to his legs. (Reid 1785: 6.5, p. 481)

D. D. Todd summarizes the point as follows:

Reid's [...] view is that belief and practice are conceptually so related that any practice will have a necessary connection with some belief or other so that the pragmatic inconsistency between the sceptics' second-order philosophical belief (that our first-order common-sense beliefs are all unjustifiable) and his first-order practice (cum belief) is really an inconsistency between belief and belief, i.e., the sceptics' pragmatic inconsistency is a form of concealed logical inconsistency. (Todd 1992: 168)

13 Suppose that this is correct. Suppose, that is, that we are "born under a necessity of trusting to our reasoning and judging powers," and that this shows that the sceptic will inevitably confront an intra-theoretical inconsistency - an inconsistency, that is, between his explicit theory, and the implicit theory manifested in his practice (Ferreira 1986: 133). Now, a further objection arises: even if we can't help believing that our faculties are reliable and/or that they issue in justified beliefs, and so even if any sceptic who puts forward a theory suggesting otherwise is bound to have inconsistent beliefs, that does not show that the former belief, or the particular beliefs formed in accordance with the first principles, are justified. In short, what positive reason do we have for regarding such beliefs 
as justified? Hookway expresses just this concern in response to Peirce's well-known claim that "[w]e cannot begin with complete doubt," and that any attempt to do so "will be mere self-deception" (CP 5.265):

[such claims] appear to be psychological statements about how we describe and conduct inquiries: unless supplemented by further argument, they do not establish that so conducting them is legitimate [...].

[A] common-sense philosophy must explain why it is legitimate to trust these certainties. This is the fundamental difficulty facing a philosophical appeal to common-sense. (Hookway 1990: 398-9) ${ }^{11}$

As we've just seen, the same concern arises in the case of Reid; and, according to some, he never provides any satisfactory response to it. Thus, for example, Galen Strawson writes:

On this, as on so many questions, there is a sense in which Reid merely rotates Hume through 90 degrees: a fact noted by Sir James Mackintosh in 1812, when he remarked to Thomas Brown that on the question of the existence of the external world Reid and Hume "differed more in words than in opinion." "Yes," answered Brown. "Reid bawled out, We must believe an outward world; but added in a whisper, We can give no reason for our belief. Hume cries out, We can give no reason for such a notion and whispers, I own we cannot get rid of it." (Strawson 1990: 15)

As against such an assessment, however, many have seen Reid as offering a real and positive advance beyond the position of Hume, and a real justification of the first principles. Among such interpreters, some have seen Reid's position on this score as having a significant pragmatist element, and one that goes beyond the Peircean ideas about belief and doubt already scouted. In the next §, we'll consider several such suggestions, and I'll enter my own proposal as to the real, and most fundamental, respect in which Reid's epistemological views exhibit a pragmatic character.

\section{Pragmatism, Narrow and Broad ${ }^{12}$}

Just what pragmatism amounts to is a matter of much dispute, partly owing to the fact that its proponents have held some subtle views, and on a whole broad range of topics, with plenty of significant disagreements among them. Here, Robert Brandom provides a helpful suggestion:

Pragmatism can be thought of narrowly: as a philosophical school of thought centered on evaluating beliefs by their tendency to promote success at the satisfaction of wants, whose paradigmatic practitioners were the classical American triumvirate of Charles Peirce, William James and John Dewey. But pragmatism can also be thought of more broadly: as a movement centered on the primacy of the practical. (Brandom 2002: 40)

The latter idea - what we might call the primacy of practice - figures centrally as well in Hilary Putnam's discussions of pragmatism. According to Putnam, along with an antisceptical and fallibilist outlook, and a suspiciousness of any fundamental fact/value dichotomy, what's most attractive and worth retaining in pragmatism is "the thesis that, in a certain sense, practice is primary in philosophy" (Putnam 1994: 52; cf. 1995: 42-52). Stanley Cavell concurs: "I think we must agree that something like this emphasis [viz., on the primacy of practice] is definitive for pragmatism" (Cavell 1998: 76).

Now, in terms of Brandom's distinction between narrow and broad conceptions of pragmatism, in providing a justification for the first principles and the beliefs formed in accordance with them, some have seen Reid as relying upon, suggesting, or needing help 
from, an element of pragmatism narrowly conceived. That is, it has been suggested that Reid relies upon (or suggests, or needs) the idea that we should evaluate beliefs, or meaning, in terms of practical success. As we'll see, each such suggestion faces difficulties, opening up space for understanding Reid as relying upon pragmatist ideas broadly construed - that is, upon the idea that practice is primary.

To begin here, consider the following passage in which, having noted that it is not in his power to distrust his senses, Reid writes:

I think it would not be prudent to throw off this belief, if it were in my power [...] I resolve not to believe my senses. I break my nose against a post that comes in my way; I step into a dirty kennel; and, after twenty such wise rational actions, I am taken up and clapped into a mad-house. Now, I confess I would rather make one of the credulous fools whom Nature imposes upon, than of those wise and rational philosophers who resolve to withhold assent at all this expense. (Reid 1764: 6.20, p. 170)

Clearly, this passage is thought by Reid to have anti-sceptical import. But why, exactly? One suggestion is that Reid is here not really offering an epistemological justification for the relevant beliefs at all. According to Peter Baumann, for example, "Reid's theory of common sense implicitly contains a dilemma" (Baumann 1999: 47). Since the first principles are first principles, we cannot argue for them directly - at least, not on the basis of anything more fundamental. ${ }^{13}$ But it doesn't follow that any such principles are true; and neither, as we saw above, does the inevitability of the relevant beliefs put scepticism to rest. So, we face a dilemma: we can continue to make truth and knowledge claims about the first principles of common sense, while acknowledging that we have no justification for doing so (dogmatism), or we can refrain from making any such claims and content ourselves with believing these things, perhaps inevitably, without any pretense to our being justified in doing so (scepticism) (Baumann 1999: 51). Clearly, neither of these options will be attractive for Reid. So, Baumann says, "[t]here must be a third way for him" (Baumann 1999: 52). According to Baumann, this third way, of which there are "hints" in Reid, is "the pragmatist way out" (Baumann 1999: 52):

Even if we cannot give justifying reasons for our principles of knowledge, we can give a totally different kind of justification: a pragmatic justification. The principles of common sense enable us to build theories which guide our actions and let us attain our goals. Insofar as they fulfill this function, they are justified and there is no place for a different kind of justification, no need to talk about truth or knowledge. (Baumann 1999: 53)

Of course, as Baumann says, Reid "does not make this last step" (ibid.). But "he is very close to this kind of pragmatism" (ibid.), and something like 'the pragmatist way out' is needed here, given our inability to provide a non-pragmatic, epistemic justification for the first principles.

Baumann's proposal is not without its problems. For one, Reid does seem to regard the first principles as epistemically, and not merely pragmatically, justified. For another, that the principles of common sense are practically useful is itself an empirical claim, the epistemic standing of which is as open to sceptical questioning as any. In response to the latter concern, Baumann clarifies that his argument "does not involve any [...] claims about the factual usefulness of common sense" (Baumann 2004: 75). All that's required are conditional judgments: "If the external world exists, then it is a more dangerous place for sceptics than for the followers of common sense. Given that we prefer not to break our noses, common sense is better off - given the existence of the external world - than 
scepticism. If the external world does not exist, then there is no difference between the two positions in terms of practical outcomes. Hence, common sense 'dominates' scepticism." (Baumann 2004: p. 75). Once again, however, it's likely that Reid would see this argument as putting things in the wrong light. For Reid emphasizes the fact that the first principles are all on a par (e.g., 1764: 6.20, pp. 168-9; 1785: 6.4, pp. 463-4). Whereas, the propounding of the decision-theoretic argument for trusting our perceptual faculties, even if it aims only at pragmatic justification, takes the reliability of reasoning in particular for granted. But, Reid asks:

Why, sir, should I believe the faculty of reason more than that of perception? - they came both out of the same shop, and were made by the same artist; if he puts one piece of false ware into my hands, what should hinder him from putting another? (1764: 6.20, p. 169)

A different proposal as to the pragmatic character of Reid's response to scepticism is discussed by Adrian Sackson. ${ }^{14}$ The proposal is that, in passages like that cited above, Reid is implicitly relying upon something like Peirce's famous 'prope-positivist' maxim:

Consider what effects, which might conceivably have practical bearings, we conceive the object of our conception to have. Then, our conception of those effects is the whole of our conception of the object. (e.g., CP 5.2, 5.402, 5.438) Thus, as applied to the present case: "Even if nature is actually 'imposing' on me this is irrelevant, since my interactions with the 'incorrectly' perceived world around me can still cause me very tangible suffering - for instance, in the form of a broken nose." (Sackson 2014: \$6). But if there is no practical difference in outcome hinging on whether scepticism is true, then "there is no justification in speaking of a difference in the concepts" (ibid.: §16). On this reading, then, Reid's argument “amounts to a pragmatist rejection of any distinction between Scepticism and anti-Scepticism which entails no difference in practical effects" (ibid.: §30).

It is doubtful, however, that Reid would accept this construal of his argument, taken at the letter. Reid does hold that ordinary use is "the arbiter of language" (Reid 1785: 1.1, p. 35); but this falls far short of the idea that the meaning of a term or concept - much less, in the manner of William James, whether a given belief is true $\mathrm{e}^{15}$ - is to be understood in terms of practical effects. ${ }^{16}$ So too, as we've seen, Reid does distinguish between real and merely professed doubt, and he thinks that genuine sceptics are an extremely rare breed. We could, if we like, cast this as a point about whether the views of one who (merely) professes scepticism are really 'meaningful,' in a more colloquial sense of the term. We could wonder, that is, whether scepticism is a 'real position' (i.e., one that's seriously believed by its proponents), and not a merely theoretical or "paper" view. But this, on its own, falls short of a face-value application of the prope-positivist maxim.

As I am understanding Reid, then, when he says, "I would rather make one of the credulous fools whom Nature imposes upon, than of those wise and rational philosophers who resolve to withhold assent at all this expense" (Reid 1764: 6.20, p. 170), the claim is heavy with irony, even ridicule. ${ }^{17} I^{\prime} d$ rather be 'imposed upon,' he's saying, as some (misguided) philosophers worry I might be - that is, I'd rather believe my senses and not come to harm - than be 'wise and rational' and end up injured and/or institutionalized. If we are massively deceived, however, all is not still well. For instance, of the idea that our sensations suggest something external, Reid says: "The belief of it, and the very conception of it, are equally parts of our constitution. If we are deceived in it, we are deceived by Him that made us, and there is no remedy." (Reid 1764: 5.7, p. 72). Not, note, 
there's no real difference here, since I'd still suffer harms if I don't trust my senses; but, there is no remedy. gmatic character of Reid's philosophy as extending only so far. Thus, for example, Eric Lundestad argues that Reid's philosophy does contain real 'proto-pragmatic' elements, especially ones present in Peirce's 'critical common-sensism' - for instance, a distinction between real versus merely professed doubt (Lundestad 2006: 131; 2008: 177), an insistence that the lack of a positive justification for certain beliefs does not itself imply doubt (Lundestad 2006: 130), and the observation that inquiry in any form arises and is carried out against the background of certain theories, beliefs and methods - certain practices (Lundestad 2006: 131). According to Lundestad, however, both a genuine pragmatism and the avoidance of dilemmas of the sort Baumann describes are not possible from within a Reidian common sense framework, which "explicitly encourages dogmatism" (Lundestad 2006: 128), and ignores the distinction between "the quaestio facti and the quaestio juris" (Lundestad 2008: 179). However, if we move away from the Reidian idea "that commonsensical beliefs may be taken as true because they are inherent to our nature" (Lundestad 2006: 132) and adopt "the pragmatic shift from theory to practice," the latter distinction becomes one that is drawn within experience: some practices 'work,' others do not; the former receive 'corroboration.' When a practice proves problematic, we may then make it an object of attention, and "the validity of this belief can only be settled by way of justification" in terms of its practical efficacy. This non-Reidian approach may not be without its problems, Lundestad says, but "there is no other way of overcoming the stalemate of common sense than by continuing to develop it" (Lundestad 2008: 184-6).

What should we to make of this? Does responding to scepticism require a shift away from Reidian common sensism, and towards a more thoroughgoing pragmatism? Only, I want now to suggest, if we are thinking of pragmatism in the narrow sense, as described above - i.e., only if we are thinking of pragmatism chiefly in terms of a focus on 'practical' matters such as the apparent benefits or effects of certain ways of acting. If we're thinking of things in this way, then the presence, or addition, of a significant pragmatist element - again, narrowly conceived - is bound to run counter to Reid's stated views in one or another way. Whereas, if we think of pragmatism more broadly, as a movement centered on the idea that practice is somehow primary, it becomes clear that what's perhaps the strongest strain of pragmatism in Reid is continuous with, and in fact inseparable from, his stated views - including, and especially, his views on common sense.

To begin, consider common sense. Colloquially, 'common sense' is often used to refer to whatever it is that's widely regarded as true ('vulgar opinion,' as Reid sometimes calls it). But Reid intends something rather narrower than this. In our discussion thus far, both Reid and his critics often speak of common sense as a specific subset of our naturally-held beliefs, or as those things that are so believed. But even this is not what's fundamental for Reid. According to Reid, 'sense' is closely connected with judgment: "in common language, sense always implies judgment. A man of sense is a man of judgment. Good sense is good judgment" (Reid 1785: 6.2, p. 424). On the relation between common sense and reason, 
Reid says that common sense is a "degree" of reason - specifically, that it is that degree of reason which is requisite for judging "of things self-evident," including the first principles, and which entitles humans "to the denomination of reasonable creatures" (Reid 1785: 6.2, p. 433). So, common sense is a specific capacity for judgment, and shouldn't be identified with the judgments and beliefs that flow from it, or with the propositions thus believed.

31 Already, note, we have the suggestion of the mixing of facts and values that Putnam associates with pragmatism (see above): 'common sense' is not merely descriptive - it suggests reasonableness, for instance. Also notable, especially in connection with a consideration of Reid's relation to pragmatism, is the fact that common sense straddles in fact, it unifies - the theory/practice distinction. Common sense enables us to judge "of things self-evident"; but a reasonable person is just as much one who "live[s] and act[s] according to the rules of common prudence" (Reid 1785: 1.2, p. 39) and is "capable of managing his own affairs, and answerable for his conduct towards others" (Reid 1785: 6.2, p. 433); it is "that degree of judgment which is common to men with whom we can converse and transact business" (Reid 1785: 6.2, p. 424). As far as common sense goes, then, there is no neat division between theory and practice, practical and theoretical rationality, or the standards of reasonableness that govern everyday life and those that the philosopher should observe:

The same degree of understanding which makes a man capable of acting with common prudence in the conduct of life, makes him capable of discovering what is true and what is false in matters that are self-evident, and which he distinctly apprehends. (Reid 1785: 6.2, p. 426)

[W] hat is absurd at the bar is so in the philosopher's chair. What would be ridiculous, if delivered to a jury of honest sensible citizens, is no less so when delivered gravely in a philosophical dissertation. (Reid 1785: 6.2, p. 475)

The mixing of psychological and normative ideas that characterizes Reid's conception of common sense is present as well in his views on evidence (Rysiew 2005, 2011a). When Reid says that the different kinds of evidence "are all fitted by nature to produce belief in the human mind" (Reid 1785: 2.20, p. 229), he clearly means that they produce belief in the sound or healthy human mind. However, it seems to be Reid's view we have no standard of cognitive 'health,' or of the properly functioning subject, that's completely independent of our most deeply held beliefs and our most fundamental epistemic practices: a significant departures from the first principles, or a failure to form beliefs in accordance with them, is not just unusual; it disqualifies one from being a "reasonable creature" - it's madness:

A remarkable deviation from [such natural and original judgments which constitute the principles of common sense], arising from a disorder in the constitution, is what we call lunacy [...]. (Reid 1764: 7, p. 215) ${ }^{18}$

Nor is this just a stipulative matter. For, in the absence of any reasonable (i.e., evidencebased) doubt as to their truth, we have no reasonable alternative to accepting the dictates of common sense. And since any evidence as to the fallaciousness of one or all of our faculties would have to presume the veracity of at least one of them, given that the first principles are all on a par, such evidence would in fact undermine the attempted argument. (So, there is an inconsistency among such a sceptic's commitments here as well.) In this sense, there could not be any reasonable (evidence-based) doubt as to the truth of the first principles. ${ }^{19}$ In this way, the first principles are constitutive principles (Rysiew 2002): accepting them is a condition - for us, given our nature - of cognizing at 
all. And insofar as it is rational to act on and believe that to which there is not - indeed, could not be - any reasonable alternative, it's rational for us to hold to the first principles of common sense.

Are the first principles really 'self-evident,' however, as Reid claims? "Can we really," Alston asks doubtfully, "see them to be true just by understanding their content?" (Alston 1985: 439). Or is there not, in Reid, simply a failure to observe the distinction "between self-evidence and being strongly inclined to believe the proposition without question" (Alston 1986: 4)? Once again, however, and independently of whether Reid's first principles really are 'self-evident' "in the classical sense" of the term, as van Woudenberg (2013: 87) puts it, a further possibility is that Reid's view is, as Alston himself elsewhere puts it, that "in a sense, there is no appeal beyond the practices we find ourselves engaged in" (Alston 1993: 130; cf. 1989). Thus, while the distinction between self-evidence and merely being strongly inclined to believe a proposition is real, and is easy to draw at the level of non-basic propositions (e.g., whether I'm going to win the lottery), since the first principles are first principles, their being self-evident and our all being strongly inclined to believe them are, as one might expect, not in practice separable. And so too, on this reading, for our accepting the first principles and our being justified in accepting them: they typify, even define, what (self-)evidentness is for us, given our constitution. The simple (apparent) manifestness of certain things, the bruteness of certain such judgments, is in the end the final court of epistemic appeal. Both the sceptic and the dogmatist fail to see this, however: both hold, if only implicitly, that epistemic justification requires an appeal to something deeper - hence their common belief that the first principles and the beliefs they undergird are without justification.

It's a large and important question how plausible the view I've just sketched is, both as a reading of Reid, and as an independently plausible position. ${ }^{20}$ For present purposes, however, what's most important is that, insofar as that view has some prima facie plausibility as an interpretation of Reid, it provides an understanding of his relation to pragmatism, and of the relation of common sense to the pragmatist elements of his views, that differs significantly from the discussions canvassed above. Specifically, as with pragmatism broadly construed, along with his anti-scepticism and his regarding certain central epistemic notions having both descriptive and normative aspects, there is a good sense in which practice - in particular, our natural and basic ways of forming and evaluating beliefs; what Alston (1989) calls our 'doxastic practices' - is primary for Reid. But common sense, as we've seen, is deeply implicated in those fundamental practices: it supplies the 'good judgment' that leads us to accept the first principles, to form beliefs in accordance with them, and to think and act the part of reasonable creatures. ${ }^{21}$ Thus, far from being at odds with, or needing supplementation by, the relevant pragmatist elements in Reid, common sense is inseparable therefrom.

In the next $\S$, I present a preliminary case that something very much like this is true of Wittgenstein's later work as well. While the discussion will be briefer than the preceding discussion of Reid, it's hoped that it will be plausible and interesting enough to suggest that the ideas therein merit further investigation.

\section{Judgment and Practice in Wittgenstein}


under the title On Certainty. In the latter work, Wittgenstein's concern is to get clear on the nature and epistemic status of propositions of the sort that Moore $(1925,1939)$, famously, sought to defend. Whether these notes contain a single and cohesive philosophical view, and if so the precise character thereof, is of course a matter of much controversy. Here, I don't pretend to be offering anything like a systematic treatment of the relevant writings, the correct interpretation of which is a matter of lively debate. The concern, rather, is with some quite general and clearly discernable features of that work and, in particular, with the general such features that constitute significant points of agreement with Reidian ideas described above.

Thus, just as, for familiar regress-related reasons, Reid takes it as obvious that there must be 'first principles' (e.g., 1785: 1.2, p. 39), and just as he rejects as both impossible and unreasonable the demands of Cartesian epistemology, Wittgenstein thinks that complete doubt makes no sense - in any inquiry, there must among our starting points be some things of which we are certain:

If you tried to doubt everything you would not get as far as doubting anything. The game of doubting itself presupposes certainty. (Wittgenstein 1969: §115; cf. §§114, $315,322,354,450,519$ )

A doubt without an end is not even a doubt. (Wittgenstein 1969: \$625)

If the shopkeeper wanted to investigate each of his apples without any reason, for the sake of being certain about everything, why doesn't he have to investigate the investigation? (Wittgenstein 1969: §459) ${ }^{23}$

So, as with Reid (and Peirce), the mere possibility of error is not a reason to doubt (1969: §4): "we are not in doubt because it is possible for us to imagine a doubt" (Wittgenstein 1953: \$84). Rather, it must be that one doubts on specific grounds (Wittgenstein 1969: $\S \S 458,122,323,519)$. And those grounds, in turn, must be grounded on things we do not doubt: "the questions that we raise and our doubts depend on the fact that some propositions are exempt from doubt, are as it were like hinges on which those turn" (Wittgenstein 1969: §341); “We just can’t investigate everything, and for that reason we are forced to rest content with assumption. If I want the door to turn, the hinges must stay put." (Wittgenstein 1969: §343). Further, the preceding are not merely descriptive points. Rather, our pretheoretic certainties have a certain type of authority, in that serious departures from them aren't just atypical, indeed not merely mistakes, but madness:

If Moore were to pronounce the opposite of those propositions which he declares certain, we should not just not share his opinion: we should regard him as demented. (Wittgenstein 1969: §155; cf. § 71)

In order to make a mistake, a man must already judge in conformity with mankind. (Wittgenstein 1969: \$156)

This does indeed point to one kind of use for "I know." "I know it is so" then means: It is so, or else I’m crazy. (Wittgenstein 1981: §408)

As with Reid's first principles, the relevant propositions are seldom made the object of thought - most likely, we think of them only when a philosopher brings them to our attention. Even so, they implicitly govern the relevant forms of activity, cognitive and otherwise. So too, just as Reid says that "[m]en need not be taught" (Reid 1785: 1.2, p. 39) the first principles, the relevant propositions according to Wittgenstein are not things in which we're instructed (Wittgenstein 1969: \$\$152-3, e.g.), and are not the product of experience (Wittgenstein 1969: \$\$130-1). Rather, they are 'swallowed down,' as consequences, in the course of learning the things we do (Wittgenstein 1969: §143). The propositions in question make up the 'frame of reference' (Wittgenstein 1969: §83) or 
'inherited background' (Wittgenstein 1969: §94) in terms of which we learn, make sense of experiences, and so forth. There is nothing more certain that could serve as reason either for or against them. ("What is to be tested by what?" [Wittgenstein 1969: §125].) Because they have such a fundamental status, if we could doubt any of Moore's propositions, we would have no reason not to doubt anything else, including the reliability of our senses:

If a blind man were to ask me "Have you got two hands?" I should not make sure by looking. If I were to have any doubt of it, then I don't know why I should trust my eyes. For why shouldn't I test my eyes by looking to find out whether I see my two hands? (Wittgenstein 1969: \$125; cf. 1953: 221)

Here, the entire framework within which we raise doubts and answer them would collapse - it would be an "annihilation of all yardsticks" (Wittgenstein 1969: \$492; cf. $\S \S 125,234,308,419,490,506,507,514,613,614,672)$. The fact is, though, that the "reasonable man does not have certain doubts" (Wittgenstein 1969: §220).

As noted above, as with the specific character of Reid's epistemology, 'the epistemology of hinges' is a matter of lively debate, with similar issues at the center of each. Thus, just as with Reid's first principles, there is debate about our attitude towards hinge propositions - whether it is one of belief and, if so, whether such beliefs are propositional; so too, and again as with Reid, there is debate as to the epistemic standing of the relevant attitude whether/why it is warranted, exactly, whether it constitutes knowledge, and so on. ${ }^{24}$ Once again, however, of special interest here are the apparent broad similarities between Reid and (the later) Wittgenstein as regards pragmatism and common sense. Beginning with the former, while many have found "a distinct pragmatic streak" in Wittgenstein's later work (Passmore 1966: 424), ${ }^{25}$ it's fairly clear that Wittgenstein, like Reid, rejects the view - and so, e.g., the response to scepticism - that meaning or truth is a matter of utility or practical effects. Very briefly: while he had earlier (1961) taken naming to be the model of meaning, in his later philosophy Wittgenstein recommends that, in most cases, the meaning of a term is best explained by describing its use (Wittgenstein 1953: §43). But this is distinct from a general identification of meaning and use; much less is it an identification of meaning with practical effects.

Wittgenstein also explicitly rejects a Jamesian conception of truth:

But you aren't a pragmatist? No. For I am not saying that a proposition is true if it is useful. (Wittgenstein 1980: §266)

And he likewise denies that 'hinge propositions,' and/or the practices in which they figure, have an essentially pragmatic justification:

No, experience is not the ground for our game of judging. Nor is its outstanding success. (Wittgenstein 1969: \$131)

This game proves its worth. That may be the cause of its being played, but it is not the ground. (Wittgenstein 1969: §474)

In short, in terms of Brandom's distinction, Wittgenstein, no less than Reid, seems not to accept pragmatism narrowly conceived (cf. Goodman 1998: 102-3; Moyal-Sharrock 2004: 171). Yet - and again, as with Reid - there does seem to be a heavy strain of the broad form of pragmatism discussed earlier (cf. Moyal-Sharrock 2004: 172) ${ }^{26}$ Thus, while (as in some of the passages above) Wittgenstein like Reid often speaks of the special character of certain propositions, as in Reid this is not separable from the role they play in action (cf. Goodman 1998: 94; e.g., Wittgenstein 1969: $\$ \$ 120,144,204,342$, 402). Further, it is not particular actions, but rather the more general practices in which they are embedded our taking certain sorts of things but not others to constitute evidence, grounds for 
doubt, legitimate forms of inquiry, and so on (e.g., Wittgenstein 1969: §§105, 151, 185, 231, $497,608)$ - on which both explanations and justifications ultimately ground out:

the end is not an ungrounded presupposition: it is an ungrounded way of acting. (Wittgenstein 1969: §110)

If I have exhausted the justifications I have reached bedrock, and my spade is turned. Then I am inclined to say: "This is simply what I do." (Wittgenstein 1953: \$217)

What has to be accepted, the given, is - so one could say - forms of life. (Wittgenstein 1953: 226)

Our mistake is to look for an explanation where we ought to look at what happens as a 'proto-phenomenon.' That is, where we ought to have said: this language-game is played. (Wittgenstein 1953: \$654)

The danger here, I believe, is one of giving a justification of our procedure when there is no such thing as a justification and we ought simply to have said: that's how we do it. (Wittgenstein 1967: II, \$74)

The essence of the language game is a practical method (a way of acting) - not speculation, not chatter. (Wittgenstein 1993: \$399)

Thus, while Wittgenstein's concern is to get clear on the nature and epistemic status of propositions of the sort that Moore sought to defend, his own view is that such propositions are not themselves what's fundamental. Even if they have a special status therein, 'hinges' are not separable from our practices; in fact, in some good sense they owe their special status to the latter: "hinges are what they are in virtue of a human practice that has developed as it has" (Coliva 2016: 94); they are "rooted, albeit not ratiocinatively, in our human form of life and in the various forms of human life" (MoyalSharrock 2016: 110).

of course, we have yet to mention common sense here. In fact, as Nyíri (2015) notes, Wittgenstein does not use 'common sense' - or its German equivalent - in On Certainty (though he does in other places). ${ }^{27}$ But that common sense is not an explicit part of the story doesn't mean that it's not deeply implicated therein. On the contrary: if, as I've just suggested, Wittgenstein's later philosophy illustrates 'the primacy of practice,' the latter in turn is inseparable from what, to a reader of Reid, would look very much like the latter's common sense - that is, a capacity for good judgment that operates in both thought and action and entitles us "to the denomination of reasonable creatures" (Reid 1785: 6.2, p. 433).

Thus, in attempting to clarify the status of Moore-style propositions, Wittgenstein frequently invokes the idea of the reasonable person as somehow fundamental. For instance,

There cannot be any doubt about it for me as a reasonable person. - That's it. (Wittgenstein 1969: \$219)

The reasonable man does not have certain doubts. (Wittgenstein 1969: \$220)

Our not doubting [Moore-style propositions] is simply our manner of judging, and therefore of acting. (Wittgenstein 1969: §232)

The latter passage, note, no less that the earlier-noted emphasis on action, makes clear that there's no hard-and-fast theory/practice distinction here - like the most-often implicit beliefs Reid speaks of, the relevant judgments for Wittgenstein are not mere dry intellectual verdicts; they govern our actions, cognitive and otherwise. The passages just above also illustrate the close connection between the idea of the reasonable person and the fundamentality of certain shared judgments, including 'agreements in judgment' (Wittgenstein 1953: §§241-242) as to what is to count as certain, as evidence, or as reason 
to doubt (cf. Ferreira 1986: 118). As Wittgenstein puts it, "We use judgments as principles of judgment" (Wittgenstein 1969: §124).

I am not more certain of the meaning of my words than I am of certain judgments

[...]. (Wittgenstein 1969: §126)

From a child on up I learnt to judge like this. This is judging. (Wittgenstein 1969:

\$128)

This is how I learned to judge; this I got to know as judgment. (Wittgenstein 1969:

$\S 129 ; \mathrm{cf}$. §§140, 149) not just something personal” (Wittgenstein 1969: §440; Greco 2016: 310-1). ("We might speak of fundamental principles of human enquiry," Wittgenstein says (1969: §670).) For example, that I [PR] am a human being is such that, if I know it of myself, every person knows it of him/herself (Wittgenstein 1969: §100). In the same manner, that I've never been to Asia Minor is something such that, if I know it of myself, then so does every normal, sane person who's had the relevant similar life experiences. And then too, there are some 'hinges' that are more obviously impersonal and shared - e.g., that there are physical objects (Wittgenstein 1969: §35), or that what has always happened will happen again (or something like it) (Wittgenstein 1969: §135); and these in turn can ground more specific judgments (e.g., that if I light a fire, it will warm us up), which might themselves function as certainties in more local contexts. In short, it's natural to see the more specific-seeming hinges as being under-written by more general ones, with the latter being more obviously held in common by all reasonable people, just as Reid's first principles are said to be. ${ }^{29}$ 


\section{Conclusion}

As we began by noting, a number of philosophers have remarked on the close affinity between the epistemological views of Reid and those of the later Wittgenstein. Here, while doing my best to remain neutral as to the specific character of their respective positions, I have suggested that these similarities include a shared commitment to an idea that, according to several commentators, is central to pragmatism, broadly understood the idea, namely, that practice is somehow primary. Further, I have argued that while the commitment to common sense is, as one might expect, much more explicit in Reid, Wittgenstein too gives fundamental place to the ideas of the reasonable person and of good judgment, as manifested in both thought and action. No doubt, plenty of questions remain about the details of Reid's and Wittgenstein's views; and no doubt too, there may be important differences between them. Nevertheless, in both figures' work there appears to be a close connection between common sense and the elements in their thought that can be considered pragmatist in some interesting and important respect.

\section{BIBLIOGRAPHY}

ALSTON William, (1985) “Thomas Reid on Epistemic Principles," History of Philosophy Quarterly, 2, $435-52$.

ALSTON William, (1986) “Epistemic Circularity," Philosophy and Phenomenological Research, 47 (1), $1-30$.

ALSTON William, (1989) “A 'Doxastic Practice’ Approach to Epistemology,” in Marjorie Clay \& Keith Lehrer (eds.), Knowledge and Scepticism, Boulder Colorado, Westview Press, 1-29.

ALSTON William, (1993) The Reliability of Sense Perception, Ithaca and London, Cornell University Press.

BAUmann Peter, (1999), “The Scottish Pragmatist? The Dilemma of Common Sense and the Pragmatist Way Out," Reid Studies, 2, 47-57.

BAUmann Peter, (2004), “On the Subtleties of Reidian Pragmatism: A Reply to Magnus," The Journal of Scottish Philosophy, 2 (1), 73-7.

BRANDOM Robert, (2002), "Pragmatics and Pragmatisms," in James Conant \& Urszula M. Zeglen (eds.), Hilary Putnam: Pragmatism and Realism, London \& New York, Routledge, 40-58.

BURAS Todd \& Rebecca COPENHAVER (eds.), (2015), Mind, Knowledge and Action: Essays in Honour of Reid's Tercentenary, Oxford, Oxford University Press.

CAVEll Stanley, (1998), "What's the Use of Calling Emerson a Pragmatist?," in Dickstein Morris (ed.), The Revival of Pragmatism, 72-80.

CoLIVA Annalisa, (2016), “Which Hinge Epistemology?," International Journal for the Study of Skepticism, 6 (2-3), 79-96. 
CONANT James \& Urszula M. ZEGLEN (eds.), (2002), Hilary Putnam: Pragmatism and Realism (Routledge Studies in Twentieth Century Philosophy), London \& New York, Routledge.

CUNEO Terence, (2004), “Critical Notice of De Bary's Thomas Reid and Skepticism," The Journal of Scottish Philosophy, 2 (2), 194-99.

DE BARY Philip, (2002), Thomas Reid and Scepticism: His Reliabilist Response, New York, Routledge. DESCARTES René, (1988), Selected Philosophical Works, translated by John Cottingham, Robert Stoothoff, \& Dugald Murdoch, Cambridge, Cambridge University Press.

ENGEL-TIERCELIN Claudine, (1989), "Reid and Peirce on Belief," in Melvin Delgarno \& Eric Matthews (eds.), The Philosophy of Thomas Reid, London, Kluwer, 205-24.

FERREIRA M. Jamie, (1986), Scepticism and Reasonable Doubt, Oxford, Clarendon Press.

FORGUSON Lynd, (1989), Common Sense, London and New York, Routledge.

Goodman Russell B., (1998), “Wittgenstein and Pragmatism,” Parallax, 4 (4), 91-105.

GRANDI Giovanni, (2008), "Reid on Ridicule and Common Sense," The Journal of Scottish Philosophy, 6 (1), 71-90.

GRECO John, (2016), “Common Knowledge," International Journal for the Study of Skepticism, 6 (2-3), 309-25.

HAACK Robin, (1982), “Wittgenstein's Pragmatism,” American Philosophical Quarterly, 19 (2), 163-71 HENSLEY Judy M., (2012), “Who's Calling Wittgenstein a Pragmatist?,” European Journal of Pragmatism and American Philosophy, 4 (2), 27-35 [http://journals.openedition.org/ejpap/716]. ноокWAY Christopher, (1990), “Critical Common-sensism and Rational Self-Control," Noûs, 24 (3), 397-411.

JACKSON Nate, (2014), “Common Sense and Pragmatism: Reid and Peirce on the Justification of First Principles," Journal of Scottish Philosophy, 12 (2), 163-79.

JAMES William, (1907), Pragmatism: A New Name for Some Old Ways of Thinking, Cambridge, MA, Harvard University Press.

KANT Immanuel, (2004 [1783]), Prolegomena to Any Future Metaphysics, translated and edited by Gary Hatfield, Cambridge and New York, Cambridge University Press.

LEMos Noah, (2004), Common Sense: A Contemporary Defense, Cambridge, Cambridge University Press.

LUNDESTAD Erik, (2006), “The Sceptic and the Madman: The Proto-Pragmatism of Thomas Reid," Journal of Scottish Philosophy, 4 (2), 125-38.

LUNDESTAD Erik, (2008), “The Necessity of Pragmatism: Overcoming the Stalemate of Common Sense," Journal of Scottish Philosophy, 6 (2), 175-87.

MAGNuS P. D., (2004), "Reid's Dilemma and the Uses of Pragmatism," Journal of Scottish Philosophy, 2 (1), 69-72.

MAGNuS P. D., (2008), “Reid's Defense of Common Sense," Philosophers' Imprint 8 (3), [http:// hdl.handle.net/2027/spo.3521354.0008.003].

MEYERS Robert G., (1967), "Peirce on Cartesian Doubt," Transactions of the Charles S. Peirce Society, 3 (1), 13-23. 
MOORE G. E., (1925), “A Defence of Common Sense," in J. H. Muirhead (ed.), Contemporary British Philosophy (2nd series), London, George Allen \& Unwin Ltd, 193-223. Reprinted in Moore (1959), 32-59.

MOORE G. E., (1939), "Proof of an External World," Proceedings of the British Academy, 25, 273-300. Reprinted in Moore (1959), 127-50.

MOORE G. E., (1959), Philosophical Papers, London, George Allen \& Unwin Ltd.

MOYAL-SHARROCK Danièle, (2004), Understanding Wittgenstein's On Certainty, Houndmills (Basingstoke, Hampshire) and New York, Palgrave-Macmillan.

MOYAL-SHARROCK Danièle, (2016), “The Animal in Epistemology: Wittgenstein's Enactivist Solution to the Problem of Regress," International Journal for the Study of Skepticism, 6 (2-3), 97-119.

NEWMAN Lex, (2016), "Descartes' Epistemology," The Stanford Encyclopedia of Philosophy (Winter 2016 Edition), Edward N. Zalta (ed.), [https://plato.stanford.edu/archives/win2016/entries/ descartes-epistemology/].

NYíRI Kristóf, (2015), “Wittgenstein and Common-Sense Philosophy," in András Benedek \& Kristóf Nyíri (eds.), Beyond Words: Pictures, Parables, Paradoxes, Frankfurt/M., Peter Lang Edition, 231-44.

PASSMORE John, (1966), A Hundred Years of Philosophy, 2nd edition, Middlesex and New York, Penguin Books.

PEIRCE C. S., (1994), The Electronic Edition of The Collected Papers of Charles Sanders Peirce (CP). Vols. 1-6 edited by Charles Hartshorne and Paul Weiss; vols. 7-8 edited by A. W. Burks. Cambridge, Belknap Press of Harvard University Press, 1958-1966.

PIHLSTRÖM Sami, (2012), “A New Look at Wittgenstein and Pragmatism,” European Journal of Pragmatism and American Philosophy, 4 (2), 9-26 [http://journals.openedition.org/ejpap/715].

PLANT Bob, (2003), “Our Natural Constitution: Wolterstorff on Reid and Wittgenstein," Journal of Scottish Philosophy, 1 (2), 157-70.

POoRE Gregory, (2015), “Theism, Coherence, and Justification in Thomas Reid's Epistemology,” in Buras \& Copenhaver (eds.), Mind, Knowledge and Action: Essays in Honour of Reid's Tercentenary, Oxford, Oxford University Press, 213-30.

PRITCHARD Duncan, (2016), Epistemic Angst: Radical Skepticism and the Groundlessness of our Believing, Princeton and Oxford, Princeton University Press.

PUTNAM Hilary, (1994), Words and Life, Cambridge, Harvard University Press.

PUTNAM Hilary, (1995), Pragmatism: An Open Question, Oxford \& Cambridge, Blackwell.

REID Thomas, ([1764]/1997), An Inquiry into the Human Mind on the Principles of Common Sense, edited by Derek R. Brookes, Edinburgh, Edinburgh University Press.

REID Thomas, ([1785]/1997), Essays on the Intellectual Powers of Man, edited by Derek R. Brookes, Edinburgh, Edinburgh University Press.

REID Thomas, ([1788]/2010), Essays on the Active Powers of the Human Mind, ed. K. Haakonssen \& James A. Harris, Edinburgh, Edinburgh University Press.

RYSIEW Patrick, (2002), "Reid and Epistemic Naturalism," The Philosophical Quarterly, 52 (209), 437-56. Reprinted in John Haldane \& Stephen Read (eds.), The Philosophy of Thomas Reid: A Collection of Essays, Malden, MA, Blackwell, 2003, 24-43.

RYSIEW Patrick, (2005), “Reidian Evidence,” Journal of Scottish Philosophy, 3 (2), 107-21. 
RYSIEW Patrick, (2011a), “Making it Evident: Evidence and Evidentness, Justification and Belief," in Trent Dougherty (ed.), Evidentialism and its Discontents, Oxford, Oxford University Press, 207-25.

RYSIEW Patrick, (2011b), “Reid's First Principle \#7," in New Essays on Reid, Canadian Journal of Philosophy, 41, sup1, 167-82. Reprinted in Patrick Rysiew (ed.), New Essays on Thomas Reid, London and New York, Routledge, 2015, 167-82.

RYSIEW Patrick, (2015a), “Pragmatism and Reid's ‘Third Way'," in T. Buras \& R. Copenhaver (eds.), Mind, Knowledge and Action: Essays in Honour of Reid's Tercentenary, Oxford, Oxford University Press, $178-92$.

RYSIEW Patrick, (2015b), “Thomas Reid on Language," in Margaret Cameron \& Robert Stainton (eds.), Linguistic Content: New Essays in the History of the Philosophy of Language, Oxford, Oxford University Press, 223-44.

RYSIEW Patrick, (forthcoming), "Factivity and Evidence," in Veli Mitova (ed.), The Factive Turn in Epistemology, Cambridge University Press.

SACKSON Adrian, (2014), “Avoiding Broken Noses: How 'Pragmatic' was The Philosophy of Thomas Reid?," European Journal of Pragmatism and American Philosophy, 6 (2), [https://

journals.openedition.org/ejpap/1065].

SOMERVILle James, (2002), "Review of Philip DeBary, Thomas Reid and Scepticism," Notre Dame Philosophical Reviews, [http://ndpr.nd.edu/news/23135/?id=1103].

SOSA Ernest, (2009), Reflective Knowledge: Apt Belief and Reflective Knowledge, Volume II, Oxford, Oxford University Press.

STRAWSON Galen, (1990), “What's so Good about Reid?," London Review of Books, 12 (4) (22 February), 14-5.

THÉBERT Angélique, (2015), “The Defense of the First Principles of Common Sense in Reid's Epistemology: A New Use for Track-Record Arguments," in T. Buras \& R. Copenhaver (eds.), Mind, Knowledge and Action: Essays in Honour of Reid's Tercentenary, Oxford, Oxford University Press, 193-212.

TODD D. D., (1989), “Introduction,” The Philosophical Orations of Thomas Reid, edited by D. D. Todd, translated from the Latin by S. D. Sullivan, Carbondale, IL, Southern Illinois University Press, 1-28.

TODD D. D., (1992), “Review of Lynd Forguson, Common Sense," Dialogue, 31 (01), 165-8.

VAN CLEVE James, (2003), “Lehrer, Reid, and the First of all Principles," in Erik J. Olsson (ed.), The Epistemology of Keith Lehrer, Dordrecht/Boston/London, Kluwer, 155-72.

VAN CLEVE James, (2004), "Review of Thomas Reid and the Story of Epistemology, by Nicholas Wolterstorff," Mind, 113 (450), 405-16.

VAN CLEVE James, (2015), Problems from Reid, Oxford, Oxford University Press.

VAN WOUDENBERG René, (2013), “Thomas Reid between Externalism and Internalism," Journal of the History of Philosophy, 51 (1), 75-92.

WitTGENSTEIN Ludwig, (1953), Philosophical Investigations, 2nd edition, translated by G. E. M. Anscombe, Oxford, Basil Blackwell.

WitTGEnSteIn Ludwig, (1961), Tractatus Logico-Philosophicus, translated by D. F. Pears \& B. F. McGuinness, London, Routledge \& Kegan Paul. 
WITTGENSTEIN Ludwig, (1967), Remarks on the Foundations of Mathematics, edited by

G. H. von Wright, R. Rhees \& G. E. M. Anscombe, translated by G. E. M. Anscombe, Cambridge, MA and London, England, The M.I.T. Press.

WitTGENSTEIN Ludwig, (1969), On Certainty, edited by G. E. M. Anscombe and G. H. von Wright; translated by Denis Paul and G. E. M. Anscombe, Oxford, Basil Blackwell.

WITTGENSTEIN Ludwig, (1976), Wittgenstein's Lectures on the Foundations of Mathematics, Cambridge, 1939, edited by Cora Diamond, Hassocks, Sussex, The Harvester Press, Ltd.

WITTGENSTEIN Ludwig, (1980), Remarks on the Philosophy of Psychology, Vol. I., edited by

G. E. M. Anscombe and G. H. von Wright, translated by G. E. M. Anscombe. Oxford, Basil Blackwell. WitTGENSTEIn Ludwig, (1981), Zettel, 2nd edition, edited by G. E. M. Anscombe and G. H. von Wright, translated by G. E. M. Anscombe, Oxford, Basil Blackwell.

WitTGENSTEIN Ludwig, (1993), "Cause and Effect: Intuitive Awareness," in James C. Klagge \&

Alfred Nordman (eds.), Philosophical Occasions: 1912-1951, Indianapolis, Hackett Publishing, 371-426. WOLTERSTORFF Nicolas, (2000), "Reid on Common Sense, with Wittgenstein's Assistance," American Catholic Philosophical Quarterly, 74 (3), 491-517.

WOLTERSTORfF Nicolas, (2001), Thomas Reid and the Story of Epistemology, New York, Cambridge University Press.

WOLTERSTORfF Nicolas, (2004), "Reid on Common Sense," in Terence Cuneo \& René van Woudenberg (eds.), The Cambridge Companion to Thomas Reid, Cambridge and New York, Cambridge University Press, 77-100.

\section{NOTES}

1. In Reid's usage, a 'proposition' is neither an abstract object nor some complex of concrete objects and properties; it is simply a complete sentence (see 1785: 1.8, pp. 69-70).

2. That, indeed, is why Reid thought that while 'an anatomy of the human mind' should be based chiefly on accurate reflection upon the operations of one's own mind, further vital sources of evidence as to the mind's basic powers and principles are the structure of language and human conduct generally (1785: 1.5, pp. 56-57).

3. Cf. Van Cleve: "When we take for granted that a faculty is reliable, we need not believe in any explicit way that the faculty is reliable. We need only have a disposition to believe its deliverances." (Van Cleve 2004: 414; emphases added). Elsewhere, van Cleve seems to allow that the latter, dispositional idea affords "one plausible sense in which ordinary subjects believe in the reliability of their faculties" (Van Cleve 2003: 161). Sosa, meanwhile (2009: 63-67), suggests that it does not much matter whether we call the relevant states or commitments beliefs; "[w]hat is important is that [the] relevant states be evaluable epistemically in the usual ways" (Sosa 2009: 66).

4. The latter are among the passages Engel-Tiercelin (1989) cites in her discussion of the similarities between Reid's and Peirce's views of belief.

5. Peirce attributes to Alexander Bain (1818-1903) the definition of a belief as "that upon which a man is prepared to act" (CP 5.12).

6. A famous instance is Kant's dismissal of an appeal to common sense as "one of the subtle discoveries of recent times, whereby the dullest windbag can confidently take on the most profound thinker and hold his own with him" (Kant 2004: 9). 
7. As we'll see shortly, it's arguable that Forguson and de Bary mischaracterize Reid's antisceptical point. Note, however, that even if his argument is, or involves, an ad hominem, that would not in his view undercut its philosophical worth. Reid is explicit, for example, that arguments ad hominem can be a legitimate means of establishing that something is a genuine first principle (1785: 6.4, p. 463).

8. In addition to Ferreira and Todd (see below), this has been argued by Cuneo 2004 and Somerville 2002.

9. See, for example, Newman's distinction, on behalf of Descartes (and as against Peirce), between belief-defeating and justification-defeating doubts (Newman 2016: §2.2). Meyers (1967: 19ff.) makes essentially the same point.

10. Pritchard makes a related point: "Beliefs [...] are propositional attitudes that by their nature are responsive to rational considerations [...]. This is not to say that beliefs are by their nature rational, of course, as this is manifestly false. It is rather to say that there are certain minimal, but constitutive nonetheless, connections between belief and truth such that a propositional attitude that didn't satisfy them simply would not count as a belief, but would be a different propositional attitude entirely. In particular, it makes no sense, for example, for there to be an agent who believes that $\mathrm{p}$ while taking herself to have no reason whatsoever for thinking $\mathrm{p}$ to be true." (Pritchard 2016: 90).

11. Compare de Bary, on what he describes as "the most crucial interpretative question about Reid's response to scepticism": "Reid may be as correct as you please, descriptively speaking, about the range of beliefs that people instinctively hold true; and he may have arrived, by abstraction, at unerring criteria for identifying these innate beliefs. But, as the sceptic will quickly point out, such psychological description is beside the epistemological point. In the absence of some link between [...] 'the Innateness Claim' and 'the Truth Claim' for first principles, the sceptical challenge to their warrant will not have been met." (2002: 37).

12. The ideas of the $\S$ are presented more fully in Rysiew 2015a, which itself draws on some earlier work. For some complementary discussion, see Jackson 2014.

13. Which is not to say that we cannot argue for them at all: some have suggested that, though they are not what give specific faculties their status as sources of evidence, 'track record' arguments for their reliability are still possible, and that Reid himself allows for such (e.g., Lemos 2004, Thébert 2015, Van Cleve 2015); and Poore 2015, e.g., argues that the justification of a first principle can, for Reid, be enhanced by coherence-style arguments from other first principles of the same standing.

14. Sackson associates this proposal with P. D. Magnus' 'argument from practical commitment.' According to the latter, "the so-called sceptic betrays a belief in the real world by managing their affairs just as common folk do" (Magnus 2004: 71). "If sceptics see that their practice implies certain beliefs, then they are left with a choice of abstaining from their practice or accepting the beliefs. Reid's argument cannot force their choice, but it makes them pay a higher price if they cleave to scepticism" (ibid.; cf. Magnus 2008: 6-7). As I understand it, Magnus' argument does not rely on any controversial claims about the (literal) meaningfulness of scepticism. The central claim, rather, recalls the discussion of the previous $\S$ as to the tenability or reasonableness of the view - which, we have been supposing, does not itself yield a positive justification for the relevant beliefs.

15. "The true is the name of whatever proves itself to be good in the way of belief, and good, too, for definite assignable reasons" (James 1907: 42).

16. Reid's views on meaning, and on language generally, are discussed in Rysiew 2015b.

17. Note that, as Giovanni Grandi 2008 has argued, Reid rejects non-epistemic conceptions of ridicule: according to Reid, it involves not just feeling but judgment, and is an important and legitimate tool of criticism. 
18. The passage continues, in a manner recalling the discussion of the previous §: "When a man suffers himself to be reasoned out of the principles of common sense, by metaphysical arguments, we may call this metaphysical lunacy; which differs from the other species of the distemper in this, that it is not continued, but intermittent it is apt to seize the patient in solitary and speculative moments; but, when he enters into society, Common Sense recovers her authority." (Ibid.).

19. Which is not to say that it's impossible, as Reid puts it, "for what is only a vulgar prejudice [to] be mistaken for a first principle" (Reid 1785: 1.2, p. 41). In general, Reid readily embraces both our fallibility and fallibilism about epistemic matters.

20. Elsewhere (2002, 2005, 2011a, forthcoming), I've begun to make a case that it is both of these things. Note that while the above reflections concerning the nature and status of the first principles may have implications for how best to interpret Reid's specific epistemological views (i.e., whether he is a reliabilist, a proper functionalist, an evidentialist, or what have you), they do not themselves determine the latter. (Compare Alston 1989: 24ff.)

21. Common sense, then, is implicated as well in the phenomena discussed in the previous $\S-$ i.e., in the sceptic's (alleged) inability to maintain consistency amongst his beliefs, and in the distinction between real and merely apparent or professed doubt.

22. Wolterstorff, e.g., speaks of "the striking similarities between Reid's and Wittgenstein's discussion of what we all do and must take for granted" (Wolterstorff 2001: 241). Others who have noted the kinship include Alston 1989, 1993; Plant 2003; Nyíri 2015; Todd 1989; and Ferreira 1986.

23. The allusion here is to Descartes' well-known analogical defense of the method doubt: "Suppose [a person] had a basket full of apples and, being worried that some of the apples were rotten, wanted to take out the rotten ones to prevent the rot spreading. How would he proceed? Would he not begin by tipping the whole lot out of the basket? And would not the next step be to cast his eye over each apple in turn, and pick up and put back in the basket only those he saw to be sound, leaving the others?" (Replies 7, AT 7: 481; 1988: 123).

24. Van Cleve (2015: Chapters 11-3) and Coliva 2016 are good entry points to the relevant literatures concerning Reid and Wittgenstein, respectively.

25. On Wittgenstein and pragmatism, in addition to other works cited herein, see e.g. those listed in Haack (1982: 171, n. 8), and the papers appearing in Vol. 4, No. 2 (2012) of this journal.

26. Cavell 1998 objects to Putnam's 1995 so reading Wittgenstein. For a response, see Hensley (2012: 30-1).

27. One example: "The philosopher is the man who has to cure himself of many sicknesses of the understanding before he can arrive at the notions of the sound human understanding [gesunden Menschenverstandes]." (Wittgenstein 1967: IV, §53). Another (reported) occurrence is this: "During this lecture Wittgenstein referred to his slogan. 'Don't treat your commonsense like an umbrella. When you come into a room to philosophize, don't leave it outside but bring it in with you." (Wittgenstein 1976: 68).

28. Moyal-Sharrock (2004: 101-4), e.g., recommends a four-fold taxonomy of 'hinges,' as linguistic, personal, local and universal. It's worth noting here that while Reid's list of first principles are most naturally read as quite general, he sometimes refers, as first principles, both to their specific instances or applications (e.g., "The truths immediately testified by the external senses are the first principles from which we reason, with regard to the material world, and from which all our knowledge of it is deduced" [1788: 3.3.6, p. 176]), and to more specific (but still general) principles (e.g., "In games of chance, it is a first principle that every side of a die has an equal chance to be turned up; and that, in a lottery, every ticket has an equal chance of being drawn out" [1785: 6.4, p. 456]), which themselves are arguably grounded upon the more general first principles Reid lists. 
29. According to Pritchard, the most general such hinge - "the über hinge" - is "that one is not radically and fundamentally mistaken in one's beliefs" (2016: 95). This corresponds to Reid's seventh first principle of contingent truths mentioned above - viz., that the natural faculties, by which we distinguish truth from error, are not fallacious (1785: 6.5, p. 480) - which Reid himself accords a special status (on which, see Rysiew 2011b). Compare here too Moyal-Sharrock's view of 'universal hinges' as "delimit[ing] the universal bounds of sense for us: they are ungiveupable certainties for all normal human beings" (Moyal-Sharrock 2004: 103), and Wolterstorff's (2000, 2001) discussion of 'maximally ingressed' beliefs as indubitable (though not infallible), with some being "deeply ingressed in the belief systems of all (normal adult) human beings" (2000: 510). A further issue is whether Wittgenstein holds, with Reid, that it is "the constitution of our nature" which leads us to hold the relevant beliefs (e.g., 1764: 2.6, p. 33). Wolterstorff thinks not; he sees Wittgenstein as someone "who tries as long as possible to make do without appealing to a shared human nature" (Wolterstorff 2000: 512). In response, Plant (2003) has argued that on this matter too Reid and Wittgenstein are, in fact, much closer than is often supposed.

\section{ABSTRACTS}

This paper considers the views of two figures whose work falls on either side of the heyday of American pragmatism, Thomas Reid (1710-96) and Ludwig Wittgenstein (1889-1951). The broad similarities between Reid's and (the later) Wittgenstein's views, and in particular their epistemological views, has been well documented. Here, I argue that such similarities extend to the relation in their work between common sense and the presence of elements in their thought that can be considered pragmatist in some important respect.

Beginning with Reid, I argue that some specific theses commonly associated with pragmatism e.g., that meaning, truth, or the justifiedness of a belief in a matter of practical effects or efficacy - clearly run counter to his stated views, and stand in tension with the well-known common sense character of his work. At the same time, however, and as others have noted, other pragmatist themes and ideas - e.g., about the close relations between belief (and doubt) and action, theory and practice, and facts and values - do have a clear precedent in Reid (\$2). Most fundamentally, however, Reid's epistemological views in particular display an adherence to the idea that practice is somehow primary - an idea that's central to pragmatism 'broadly conceived', as Brandom calls it and, according to some others (e.g., Putnam, Cavell), to pragmatism per se. What's more, once we are clear on the respect(s) in which Reid's views do incorporate an important pragmatist element, it becomes clear that far from being at odds with, or needing supplementation by, the latter, common sense is in fact inseparable from it (\$3).

Finally, I turn (\$4) to Wittgenstein, and suggest that the same close connection between pragmatist elements and common sense as we find in Reid is present here as well: like Reid, Wittgenstein rejects several 'narrow' pragmatist theses; but he too ascribes practice a crucial role. And while he seldom explicitly refers to common sense, the notions of good judgment, and of the reasonable person - hallmarks of common sense, as Reid conceives of it - are at the heart of Wittgenstein's later epistemological views as well. 
AUTHOR

PATRICK RYSIEW

University of Victoria

rysiew[at]uvic.ca 